\title{
Erosional patterns induced by coral reefs in the eastern coast of Brazil
}

\author{
Gerson FERNANDINOํㅜ, Mauricio GONZÁLEZ², Verónica CÁNOVAS², Clemente Augusto Souza \\ TANAJURA $^{3}$ \& Iracema Reimão SILVA ${ }^{4}$
}

(este artigo contem material suplementar disponível na versão eletrônica)

Programa de Pós-Graduação em Geologia, Núcleo de Estudos Hidrogeológicos e do Meio Ambiente, Instituto de Geociências, Universidade Federal da Bahia. Rua Barão de Geremoabo, s/n, Campus Federação, CEP 40170-290, Salvador, BA, Brazil. (gerson.fernandino@yahoo.com.br).

2 Instituto de Hidráulica Ambiental, Universidad de Cantabria. Avda. Isabel Torres, 15, Parque Cinetífico y Tecnológico de Cantabria, 39011, Santander, Spain (mauricio.gonzalez@unican.es, veronica.canovas@unican.es).

Departamento de Física da Terra e do Meio Ambiente, Instituto de Física, Universidade Federal da Bahia (cast@ufba.br).

Departamento de Oceanografia, Núcleo de Estudos Hidrogeológicos e do Meio Ambiente, Instituto de Geociências, Universidade Federal da Bahia (iracemars@yahoo.com.br).

Fernandino, G., González, M., Cánovas, V., Tanajura, C.A.S. \& Silva, I.R. 2018. Erosional patterns induced by coral reefs in the eastern coast of Brazil. Pesquisas em Geociências, 45: e0750.

DOI: https://doi.org/10.22456/1807-9806.91391

\begin{abstract}
Beaches are highly dynamic environments that directly respond to changes in wave climate. These changes may influence already existing erosional problems. The general objective of the present study was to describe the wave climate of the coast of Porto Seguro, eastern Brazil, to evaluate how mean and more energetic wave conditions influence local coastal dynamics, inferring possible causes of erosion focuses observed in the area. The Coastal Modeling System SMC-Brasil was used to assess mean and more energetic waves reaching the coast in order to evaluate coastal current patterns. The most frequent wave directions observed were from ESE and SE. The presence of coral reefs adjacent to the coast created zones of low wave energy and focuses of higher wave magnitude along the coast as a result of diffraction. Coral reefs and beachrock outcrops were shown to play an important role in current patterns and greatly influence the erosion focuses observed in the area, which were found to be intensified during austral autumn/winter months.
\end{abstract}

Keywords. coastal erosion, longshore transport, waves, SMC-Brasil, coastal management.

Resumo. PADRões ERosivos INDUZidos POR RECIFES DE CORAL NA COSTA LESTE Do BRASIL. Praias são ambientes altamente dinâmicos que respondem diretamente a mudanças ocorridas no clima de ondas. Essas mudanças podem influenciar problemas existentes de erosão. 0 objetivo geral do presente estudo foi descrever o clima de ondas na costa de Porto Seguro, costa leste do Brasil, avaliando como condições de ondas médias e mais energéticas podem influenciar a dinâmica costeira local, e inferindo possíveis causas para os focos de erosão observados na área. 0 sistema de modelagem costeira SMC-Brasil foi aplicado para avaliar ondas médias e mais energéticas que chegam à costa de modo a calcular padrões de correntes costeiras. As direções de ondas mais frequentes foram de ESE e SE. A presença de recifes de coral adjacentes à costa cria zonas de baixa energia de ondas e focos de maior magnitude de ondas ao longo da costa, resultantes de processos de difração. Recifes de coral e afloramentos de arenitos de praia demonstraram ter um importante papel na formação de padrões de correntes, influenciando os focos de erosão observados na área, que se mostraram intensificados durante os meses de outono/inverno austral.

Palavras-chave. erosão costeira, deriva litorânea, ondas, SMC-Brasil, gerenciamento costeiro 


\section{Introduction}

Beaches are highly dynamic environments that are deeply influenced by variations in energy (waves, winds and tides), material (sediments) and by beach morphology itself. The dynamic balance of coastal geomorphological units is defined through morphological adjustments in response to changes in sea level, sediment supply and ocean wave climate (Adams et al., 2011). However, coastal geomorphology is not only influenced by processes, but also actively influences its own form in a mutual feedback relationship between processes and shape (Masselink \& Gehrels, 2014).

An uneven distribution of wave heights along the coast causes longshore sediment transport and, therefore, leads to erosive/accumulative processes (Griggs \& Trenhaile, 1997). Thus, beach erosion is directly associated with wave climate. Areas where higher, more energetic waves occur are more susceptible to erosion than areas where smaller waves reach the coast (Bittencourt et al., 2010).

Mori et al. (2010) identified that $70 \%$ of sandy beaches in the world are currently suffering erosional processes. While erosion may not be considered a coastal hazard in all locations, the risk imposed to urban beaches may be intensified due to the removal of natural wave buffering zones in much of these areas.

This situation is clearly observed along the eastern coast of Brazil, for example. Bittencourt et al. (2005) have identified various sectors of the southern coast of the state of Bahia that are already experiencing severe coastal erosion, which threatens roads and private properties, leading to financial loss and trouble to the local population. This situation may at first seem unlikely given the presence of large coral reef patches in the area, which are usually associated with shoreline protection (Elliff \& Silva, 2017). However, the presence of these geological structures promotes complex hydrodynamic processes, which should be analyzed at a more detailed scale to allow mitigation of erosion and impacts on the shoreline.

The study of coastal dynamics depends greatly on obtaining information about sea states in a systematic and continuous way. This is particu- larly true regarding the characterization of waves that reach the shoreline and interact with natural and anthropogenic features along coastal zones (Almeida et al., 2015). Understanding how a beach functions is an important part of both coastal and oceanic studies (Liu \& Losada, 2002). These studies can, in turn, support coastal management strategies for either mitigating or adapting to current and future conditions (Silva et al., 2003).

The lack of wave data with consistent spatial and temporal resolution is a well-known problem in Brazil, as well as in other developing countries, which hampers studies regarding coastal dynamics and vulnerability (CEPAL, 2011; Almeida et al., 2015). The Coastal Modeling System SMC-Brasil (http://smcbrasil.ihcantabria.com/) was developed aiming to fill this information gap and allow the elaboration of coastal studies along the entire coast of Brazil. The system was also designed with the intention to serve as a management tool for local agents to propose and evaluate projects that interfere in the shoreline.

In this context, the objective of the present study was to describe the wave climate of the northern coast of Porto Seguro, Bahia, Brazil, using SMC-Brasil, evaluating at the greatest level of detail so far how mean and more energetic wave conditions influence local coastal dynamics in this area, inferring possible causes for the erosional hotspots observed.

\section{Area, materials and methods}

\subsection{Study area}

The study area is located within a region known as Costa do Descobrimento, southern state of Bahia, Brazil. The area encompasses the beaches of the northern coast of the municipality of Porto Seguro (Fig. 1), extending from the left margin of the mouth of the Buranhém River (indicated in fig. 2) up to the tombolo of Coroa Vermelha, at the border with the municipality of Santa Cruz Cabrália.

The southern coast of the State of Bahia presents high geodiversity and is rich in coastal environments, such as coral reefs, mangrove forests and sandy beaches. Coral reef patches are found across the continental shelf adjacent to the studied 
A

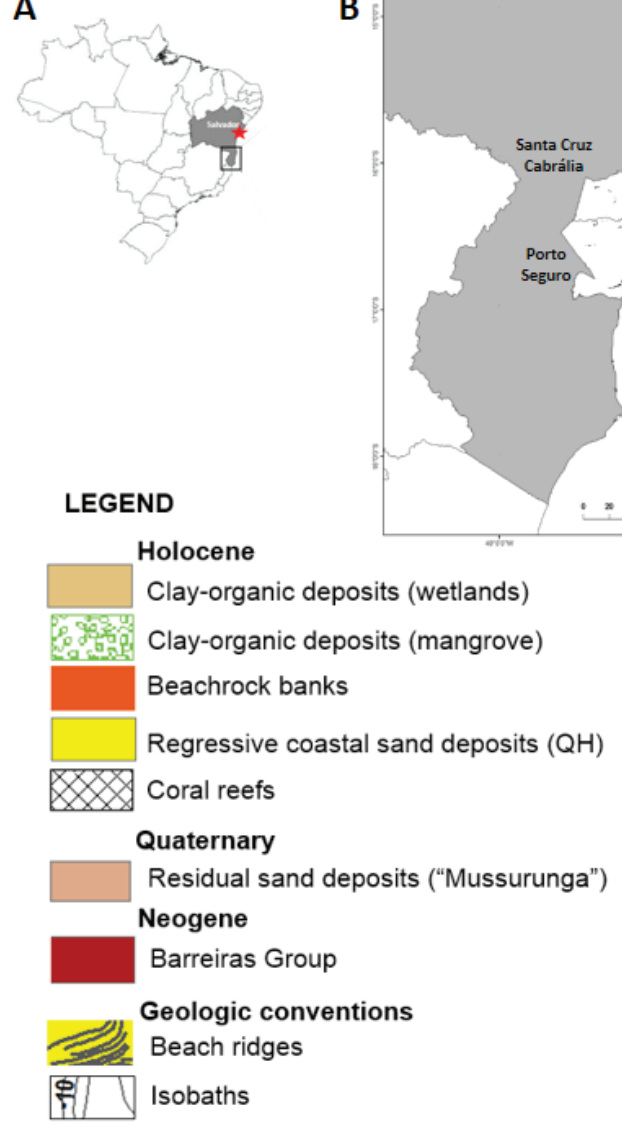

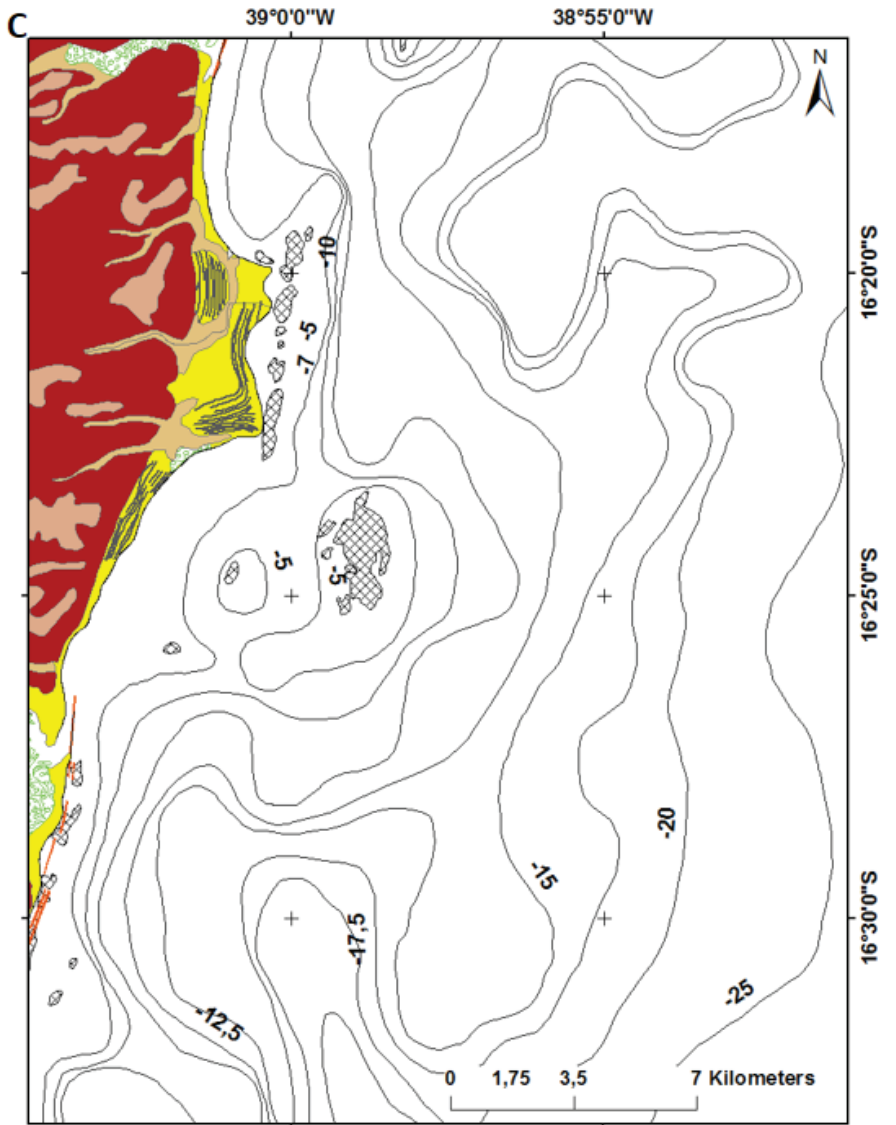

Figure 1. Location and geology setting of the study area. A) Detail (rectangle) shows the location of the study area in relation to Brazil and the state of Bahia. The star indicates the location of the capital of the state of Bahia, Salvador; B) Detail of the area of interest (rectangle): the northern coast of the municipality of Porto Seguro, Bahia; and C) Detail of the geology of the study area. Neogene sediments (Barreiras Formation) dominate the inland area while Quaternary sediments (coral reefs, beachrocks, beach and lagoon deposits) predominate along the coast. Isobaths show irregular shapes, especially near coral reefs and bottom features (geology data source: Dominguez, 2000).

Figura 1. Localização e geologia da área de estudo. A) O detalhe (retângulo) mostra a localização da área de estudo em relação ao país e ao estado da Bahia. A estrela indica a localização da capital do estado da Bahia, Salvador; B) Detalhe da área de interesse (retângulo): costa norte do município de Porto Seguro, Bahia; e C) Detalhamento da geologia da área de estudo. Sedimentos neogênicos (Formação Barreiras) dominam a porção interna, enquanto sedimentos quaternários (recifes de coral, afloramentos de beachrocks, e depósitos lagunares) predominam ao longo da costa. Isóbatas demonstram formas irregulares, especialmente próximo aos recifes de coral e feições de fundo (fonte dos dados geológicos: Dominguez, 2000).

shoreline, bordering the Coroa Vermelha, Ponta do Mutá and Ponta Grande tombolos, and the municipality of Porto Seguro (Fig. 1 and 2) (Leão \& Kikuchi, 1999).

The municipality of Porto Seguro presents various historical, cultural and natural attractions. However, the erosive characteristic of some of its beaches reduces the sand strip available for recreational activities and has caused destruction to restaurants and tourism-related buildings, thus compromising this important sector of the local economy.

Geologically, the area consists primarily of Neogene rocks (Barreiras Formation) and secondarily of Quaternary sediments (coral reefs, bea- chrocks, beach and lagoon deposits) (Dominguez et al., 2002). The beaches of Porto Seguro consist of Quaternary medium-sized sands, with a small percentage of finer grains associated with wetlands and mangrove deposits.

The area was subdivided into three sectors in the present study (from south to north): Sector 1 - from the river mouth up to the third reef patch adjacent to the coast; Sector 2 - from the third reef patch adjacent to the coast up to the Ponta Grande tombolo; and Sector 3 - from the Ponta Grande tombolo up to the northern limit of the municipality of Porto Seguro, between the tombolos of Ponta do Mutá and Coroa Vermelha (Fig. 2).

The shorelines of sectors 1 and 2 present 


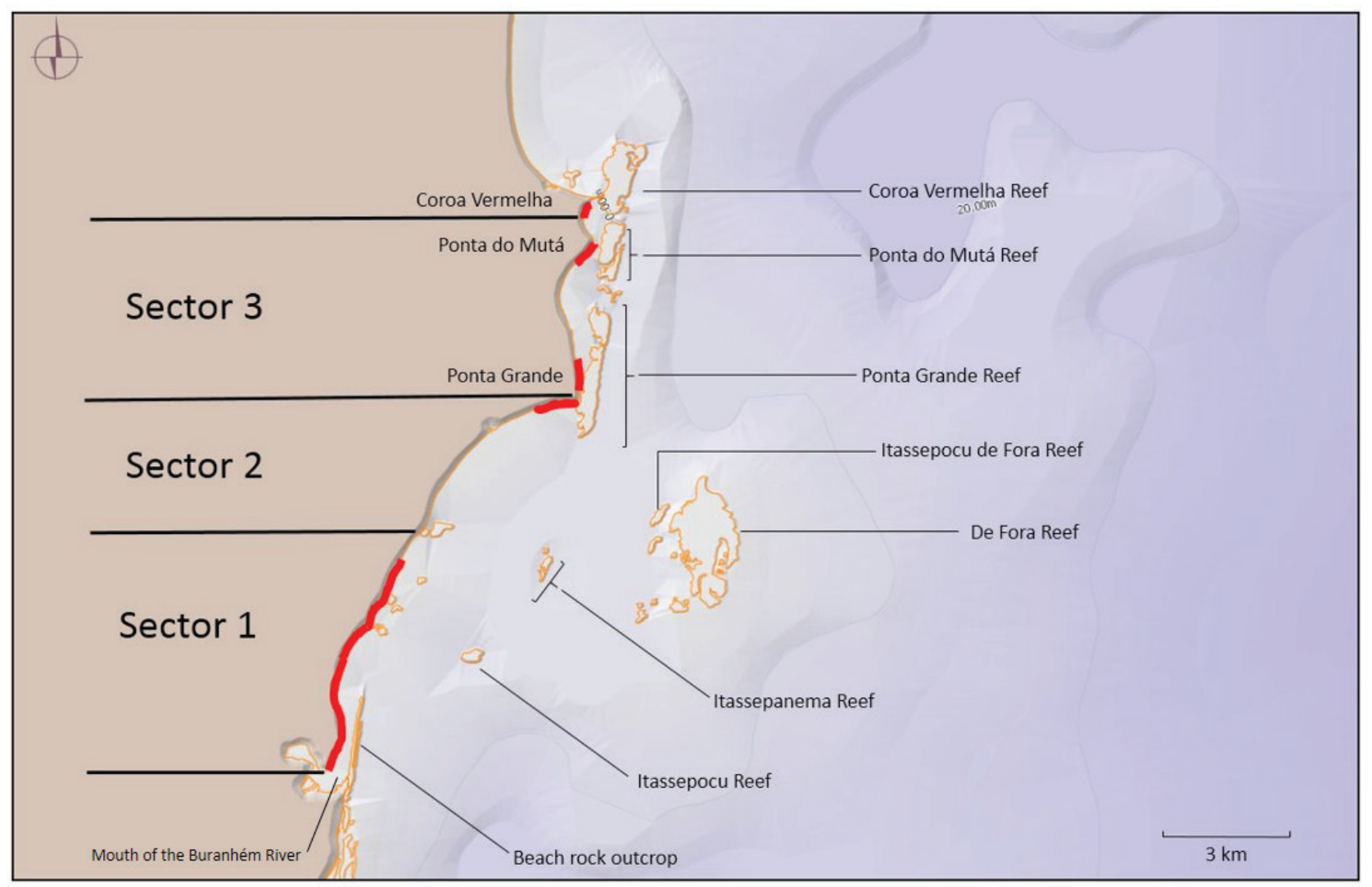

Figure 2. Beaches of the municipality of Porto Seguro subdivided into three sectors. Main reefs and beachrock outcrops are identified by name and erosional hotspots, identified by Silva (2004), are highlighted in red. Seafloor bathymetry interpolation produced with SMC-Brasil.

Figura 2. Praias do município de Porto Seguro subdivididas em três setores. Os principais recifes e afloramentos de beachrocks estão identificados por nome, enquanto os focos de erosão, identificados por Silva (2004), estão destacados em vermelho. A interpolação da batimetria foi produzida utilizando o SMC-Brasil.

relatively straight beaches with waves breaking directly on the shoreface. Reef patches that are either adjacent or even connected to the coast often interrupt these beaches. Minor salients can be observed at the back of these small patches. Sector 3 , consists of large constructive features (tombolos) located adjacent to coral reef patches. Although the study by Dominguez et al. (2002) was not conducted with high spatial resolution, complex patterns of wave transformation due to refraction and diffraction were found behind coral reefs near the coast, indicating that they might be associated with some of the erosive patterns observed in the area.

One of the most severe (and recurrent) erosive hotspots of the study area is located near the border between sectors 2 and 3. The BR-367 road, which belongs to the national highway network, is the only communication between the center of the municipality of Porto Seguro and the districts located along the Ponta Grande tombolo. In this area, the road approaches the shoreline and is constantly damaged by the erosion of the adjacent beach (Ponta Grande beach), especially during austral autumn/winter months (Mar-Apr-May/ Jun-Jul-Aug), when more energetic waves from the southeastern quadrant reach the coast (Martin et al., 1998; Bittencourt et al., 2000) (Fig. 3). Thus, a riprap was built to protect this road. However, this structure proved to be clearly inefficient in protecting the shoreline. Evidence of the high periodicity of these erosive events can be easily obtained through reports from the local media showing the damages to the road. The most recent event was reported on 13 September 2018. Consequently, there is no longer a recreational beach in the area, especially during high water conditions. In addition, the presence of the riprap itself and rocks that collapsed from this structure hamper the access to the beach, thus diminishing its recreational appeal. 


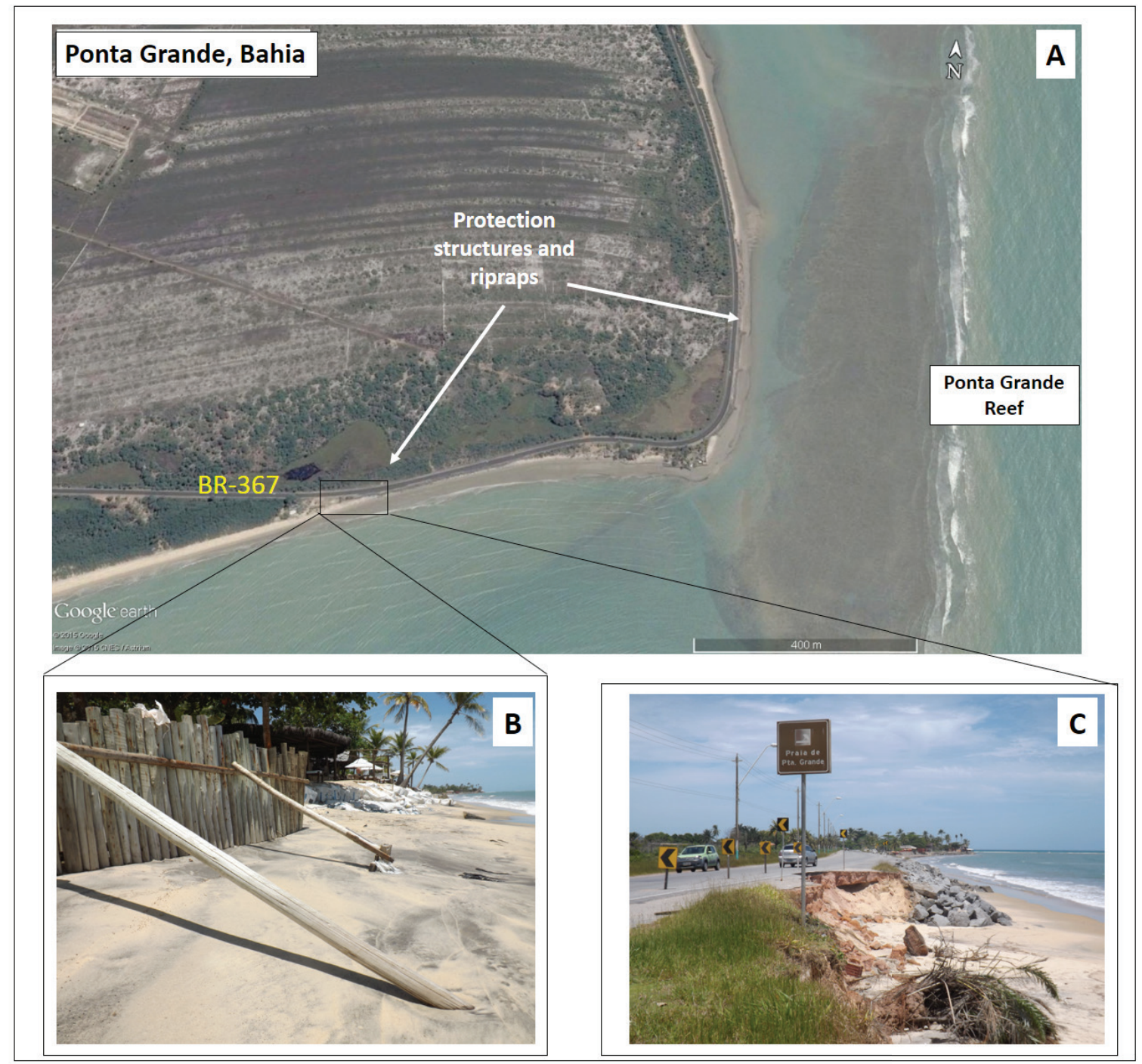

Figure 3. Detail of the Ponta Grande tombolo and damages caused by coastal erosion and actions taken to minimize its effects. A) Location of shoreline protection walls and ripraps built in order to try to minimize the effects of the coastal erosion that affects the BR-367 road (arrows) (Source: Google Earth); B) Examples of structures built to protect a private property; and C) Damage to the BR-367 road after a storm in 2016. Note the presence of a riprap (rocks) previously placed as a protective measure against erosion.

Figura 3. Detalhe do tômbolo de Ponta Grande e danos causados pela erosão e medida tomadas para combater seus efeitos. A) Localização dos muros de proteção e enrocamentos construídos para tentar minimizar os efeitos da erosão costeira que afeta a rodovia BR-367 (setas) (Fonte: Google Earth); B) Exemplo de estruturas construídas para proteger propriedades privadas; e C) Danos causados à rodovia BR-367 após uma tempestade em 2016. Note a presença de enrocamento (rochas) colocados anteriormente como medida de proteção contra erosão.

Apart from a riprap built near the road, protective structures are scarce, except in some private properties where walls were built using either concrete or wood. Sand bags were also placed in an attempt to interrupt or minimize erosive effects (see fig. 3).

In addition to the previously mentioned coral reefs, beachrock outcrops are found in the southernmost region of the study area, with either parallel or sub-parallel orientation to the shoreline and lengths ranging from 0.3 to $5 \mathrm{~km}$ (see fig. 2). 2.2 Wave, sea level and bathymetry data
The wave and sea level data used in the present study originated from the database of SMC-Brasil (Environmental Hydraulics Institute of Universidad de Cantabria - IHCantabria, Spain). This system comprises a reanalysis of global data producing sea states for every hour over the period between 1948 and 2008 (60 years), called the Global Ocean Waves (GOW) database, which allows the description of deep-water waves (Reguero et al., 2012).

The GOW database, in turn, originated the Downscaled Ocean Waves (DOW) database, which 
is embedded in SMC-Brasil (Camus et al., 2013). Wave propagation is calculated within SMC-Brasil using the OLUCA model, which interacts with the system's Model for Beach Morphodynamics (MOPLA) and models for currents induced by wave -breaking (COPLA) (González et al., 2007, 2016). Full descriptions of the SMC-Brasil methodologies and data for waves and sea level are presented by González et al. (2016) and in SMC-Brasil manuals available online at <http://smcbrasilihcantabria. com/downloads/>.

The bathymetry data initially used were obtained through the digitalization of nautical charts (chart No. 1205, scale 1: 30,000, Brazilian Navy and National Institute for Waterway Research) already integrated in SMC-Brasil. Additionally, new bathymetry data was included, with isobaths beginning at $5 \mathrm{~m}$ (Dominguez, 2000). The location and contours of coral reefs and beachrocks were manually improved based on satellite images (Google Earth Pro).

As a convention, in the present study, reefs that are not exposed during low spring tides were considered to be located at $0.5 \mathrm{~m}$ in depth, while reefs that are exposed in this condition were considered to emerge $0.5 \mathrm{~m}$ above the water.

\subsection{Selection of representative cases for describing} wave and current patterns

A DOW point (coordinates: $\mathrm{x}=565225 \mathrm{~m}$, $\mathrm{y}=8177387 \mathrm{~m}$; UTM WGS 1984, Zone 24 L), was chosen in deep waters $(\mathrm{z}=1560 \mathrm{~m})$ to initially establish general wave climate conditions.

Three coupled grids were then constructed to execute representative cases selected according to these wave climate results (see Tab. 1). However, due to limitations regarding the regionalization of the atmospheric reanalysis data incorporated in SMC-Brasil (e.g. insufficient spatial resolution of local winds) an additional ENE grid was created to propagate waves from the northeastern quadrant. Thus, four grids (ENE, E, SE and SSE) were designed. Each comprised an external grid with spatial resolution of $100 \times 100 \mathrm{~m}$ and a nested grid, with spatial resolution of $25 \times 25 \mathrm{~m}$. Eight control points were distributed along the coast in each grid (Fig. 4).

Mean cases $(\mathrm{Hs}=1.5 \mathrm{~m}, \mathrm{Tp}=7.8 \mathrm{~s})$ were attributed to the ENE and $\mathrm{E}$ grids and more energetic cases $(\mathrm{Hs}=3.0 \mathrm{~m}, \mathrm{Tp}=9.8 \mathrm{~s})$ were attributed to the SE and SSE grids. Waves were propagated to the study area through the OLUCA model (SMC-Brasil) based on the interaction of the four grids designed and local bathymetry. In turn, wave-induced coastal currents were calculated using the COPLA model, which calculates currents associated with wave breaking. The tide amplitude attributed for the propagation of these representative cases was $1.5 \mathrm{~m}$ and results were produced for a mean tide height.

\section{Results}

\subsection{Mean and more energetic wave regimes}

The combined analysis of wave height and peak period (Fig. 5) showed that the most frequent waves in the area (mean conditions) presented significant wave heights ranging between $1.0-1.5 \mathrm{~m}$ and wave periods between $6-9 \mathrm{~s}$. For more energetic conditions, wave height ranged between 3.0 - $3.5 \mathrm{~m}$ and wave periods between $9-12 \mathrm{~s}$.

Just over $50 \%$ of waves in the area origina-

Table 1. Mean and more energetic wave regimes produced using SMC-Brasil for the coast of Porto Seguro, Bahia. Tabela 1. Regimes de onda médios e mais energéticos produzidos utilizando o SMC-Brasil para a costa de Porto Seguro, Bahia.

\begin{tabular}{cccccc}
\hline Direction & $\begin{array}{c}\text { Occurrence } \\
\text { probability (\%) }\end{array}$ & $\begin{array}{c}\text { Mean wave } \\
\text { height }(\mathbf{m})\end{array}$ & $\begin{array}{c}\text { More energetic } \\
\text { wave height } \\
(\mathbf{m})\end{array}$ & $\begin{array}{c}\text { Mean wave } \\
\text { period }(\mathbf{s})\end{array}$ & $\begin{array}{c}\text { More energetic } \\
\text { wave period (s) }\end{array}$ \\
\hline ESE & 50.08 & 1.53 & 3.17 & 7.45 & 12.32 \\
SE & 33.10 & 1.57 & 3.06 & 7.21 & 13.84 \\
E & 11.30 & 1.50 & 3.05 & 8.12 & 11.66 \\
SSE & 5.17 & 1.88 & 3.33 & 9.51 & 14.87 \\
\hline
\end{tabular}



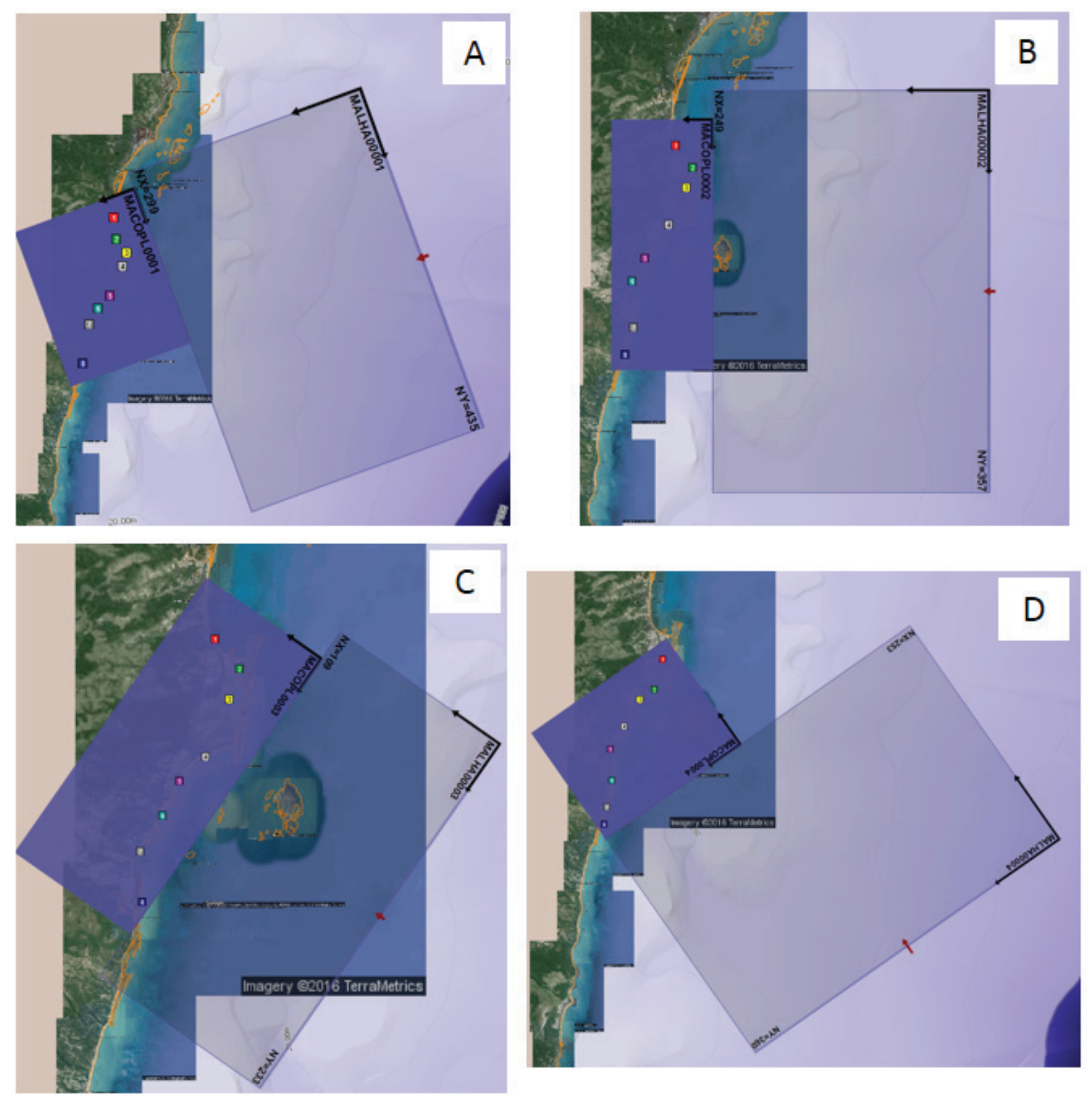

Figure 4. Wave propagation grids. A) ENE grid; B) E grid; C) SE grid; and D) SSE grid. Note the location of the control points (colored squares) distributed along the coast of Porto Seguro.

Figura 4. Malhas de propagação de ondas. A) Malha ENE; B) Malha E; C) Malha SE; e D) Malha SSE. Notar a localização dos pontos de controle (quadrados coloridos) distribuídos ao longo da costa de Porto Seguro.

ted from ESE, with mean wave height of $1.53 \mathrm{~m}$ and mean peak wave period of $7.45 \mathrm{~s}$. Under more energetic weather conditions for the same direction, mean wave height was $3.17 \mathrm{~m}$ and mean peak period was $12.32 \mathrm{~s}$. Table 1 shows a comparative summary of mean and more energetic regimes for the four main wave directions. The remaining directions presented very low occurrence probabilities and were not included in the analysis.

\subsection{Seasonal and temporal wave regimes}

During the austral spring, summer and winter months (roses A, B and D, respectively), waves from ESE predominate (Fig. 6). However, during austral autumn months (rose $\mathrm{C}$ ) there is a change in predominant wave direction, in which most waves originate from SE.

According to the generalized extreme values (GEV) presented in figure 10, which shows return 

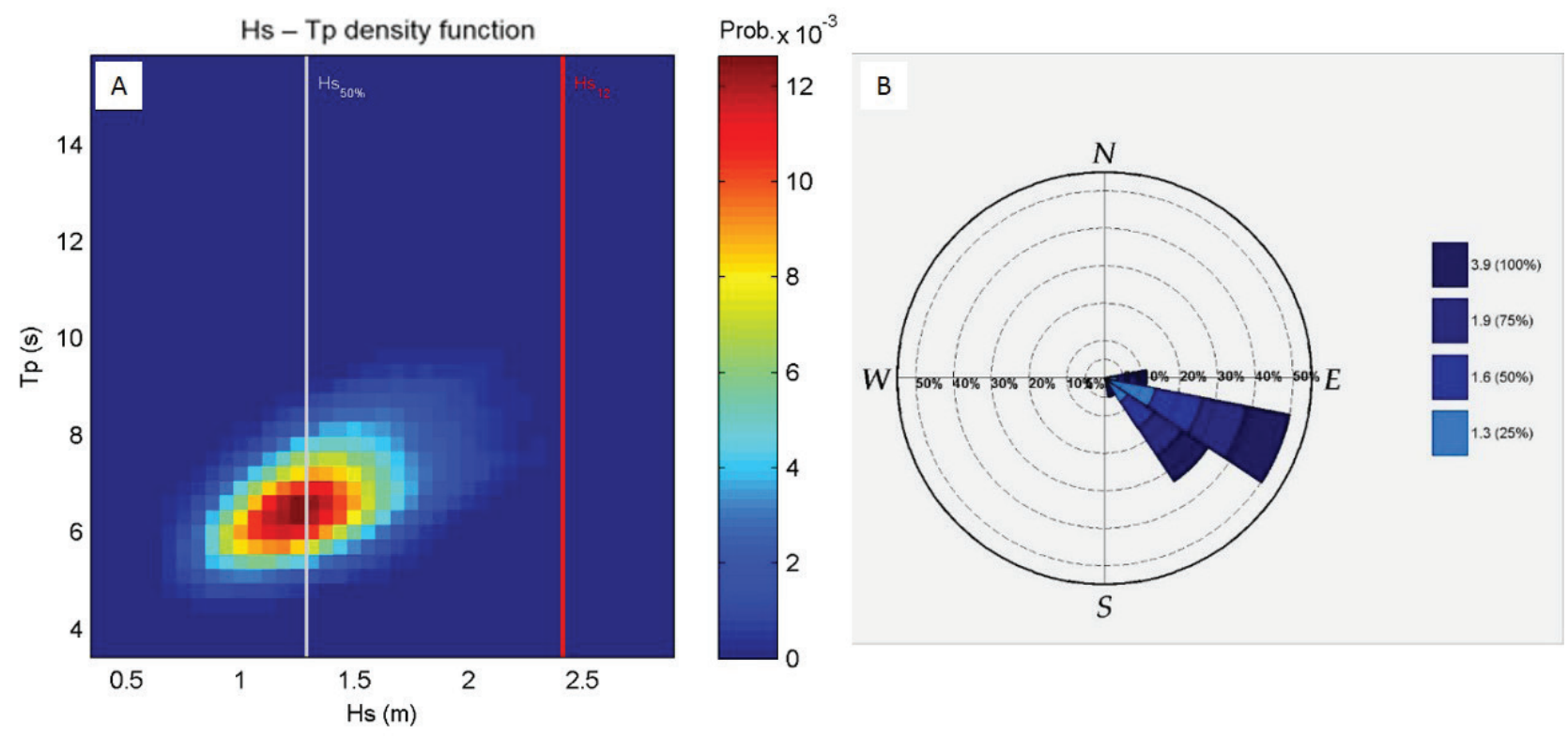

Figure 5. Wave height and peak period results. A) Combined distribution of wave height (Hs) and wave peak period (Tp); and B) Wave rose. The white line indicates $\mathrm{Hs}_{50 \%}$ and the red line indicates $\mathrm{Hs}_{12}$.

Figura 5. Resultados de altura de onda e período de pico. A) Distribuição combinada de altura de onda (Hs) e período de pico (Tp); e B) Rosa de ondas. A linha branca indica o $\mathrm{Hs}_{50 \%}$ e a linha vermelha indica o $\mathrm{Hs}_{12}$.

period data of waves approaching the studied coast, waves of approximately $3.4 \mathrm{~m}$ have a return period of five years. For this same period, waves with approximately $\mathrm{Tp}=11 \mathrm{~s}$ would occur. Waves measuring $3.8 \mathrm{~m}$, with $\mathrm{Tp}=12 \mathrm{~s}$, should reach the area every 50 years. These results indicate that more energetic waves may reach the coast of Porto Seguro at different time intervals. However, a longer temporal series may be necessary for confirming this sign presented for 50 years.

\subsection{Wave height and direction}

Wave height and direction results are shown in figures 8 and 9. In these figures, representative cases - a mean condition case (ENE waves) and a more energetic case (SSE waves) - were included for discussion. Results referring to $\mathrm{E}$ and SE waves are provided as Supplementary Material.

In general, mean waves from ENE and E presented similar orders of magnitude. Waves from these directions reach the shoreline with low energy because of the transformations they undergo in shallow waters due to bathymetry and the presence of natural obstacles such as coral reef patches (Fig.8A and Supplementary Material). More energetic waves (from SE and SSE) also presented si- milar orders of magnitude, however they reach the coast with more energy, especially in the northern portion of Sector 2, at the tombolo of Ponta Grande, where the most severe erosional hotspot can be observed (Fig. 8B and Supplementary Material).

Reefs in the study site, especially the De Fora Reef (the largest), cast a low wave energy area (shade zone) over the adjacent coast. These shade zones changed according to wave direction and were observed under both mean and more energetic conditions, though more evident during the latter.

The reefs adjacent to the tombolos of Ponta Grande, Ponta do Mutá and Coroa Vermelha (Sector 3), as well as the beachrock outcrop in the southernmost region of Porto Seguro (Sector 1), also produced a shade zone that partly protected adjacent beaches from direct wave action, especially during mean wave conditions. On the other hand, the presence of channels and openings between and within these reefs allows the entrance of diffracted waves, which reach the coast with higher erosive potential due to the relatively greater depth of their path (Fig. 9).

The Ponta Grande reef provided greater shoreline protection from ENE (Fig. 9A) and E waves (Supplementary Material) to the beaches located 


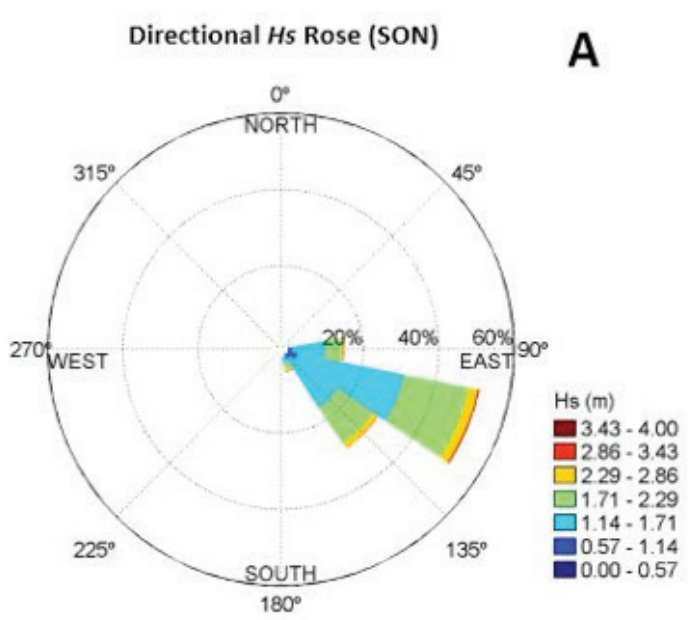

Directional Hs Rose (MAM)

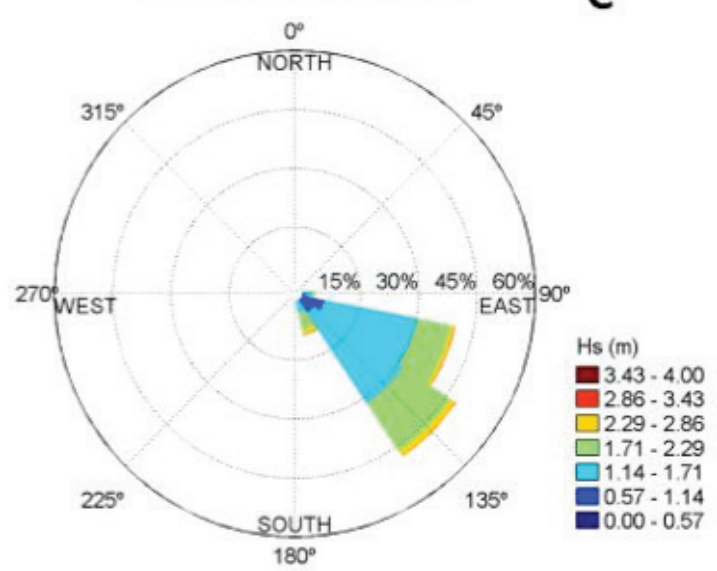

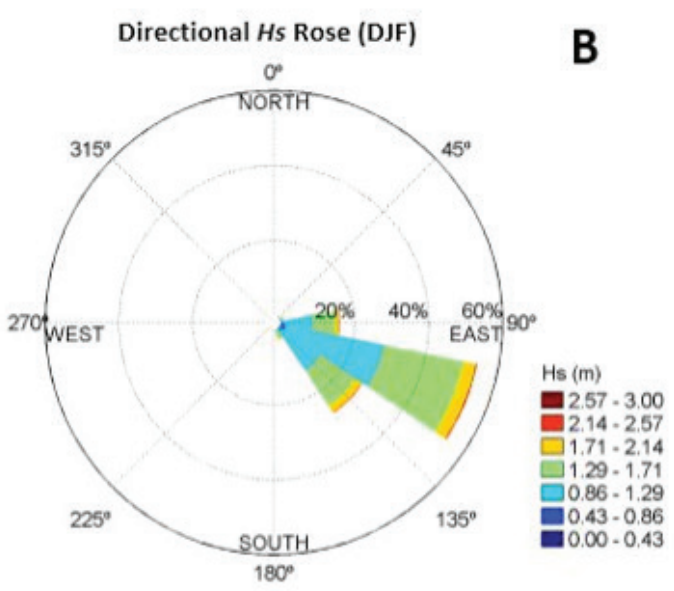

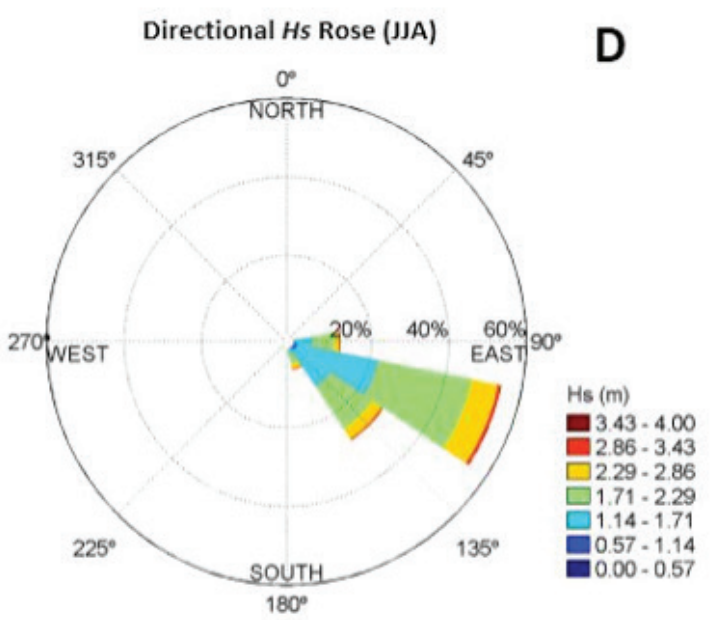

Figure 6. Seasonal wave regime for Porto Seguro. A) Austral spring; B) Austral summer; C) Austral autumn; and D) Austral winter. SON: September, October, November; DJF: December, January, February; MAM: March, April, May; and JJA: June, July, August. Figura 6. Regime de ondas sazonal de Porto Seguro. A) Primavera austral; B) Verão austral; C) Outono austral; e D) Inverno austral. SON: setembro, outubro, novembro; DJF: dezembro, janeiro, fevereiro; MAM: março, abril, maio; e JJA: junho, julho, agosto.

in the northern portion of the study area (northern area of Sector 2 and the entire Sector 3). This included the southern area of the Ponta Grande tombolo, near the BR-367 road. The diffraction produced by the southernmost extremity of this reef directs waves towards the border between sectors 1 and 2. Therefore, diffraction processes direct waves with higher magnitude southwards, which reach the beach quasi-perpendicularly.

In the case of SE (Supplementary Material) and SSE waves (Fig. 9B), more intense refraction and diffraction was observed associated, mainly, with the De Fora reef, thus allowing waves with higher magnitudes to reach the area between sectors 1 and 2. For these waves, there was a northward migration of protected zones, a complete elimina- tion of the shade zone created by the Ponta Grande reef in the northern portion of Sector 2, and a decrease of these zones along the beaches located behind these reefs. These conditions allowed more energetic waves to reach these areas.

\subsection{Currents along the coast of Porto Seguro}

Similarly to the wave height and direction results, coastal current results for all four cases (E, ENE, SE, and SSE) were included as Supplementary Material. Figures 10 and 11 were included presenting the results for $\mathrm{E}$ and SE waves in order to illustrate the discussion. More details on current vectors can be seen in the Supplementary Material. In general, currents produced by mean 

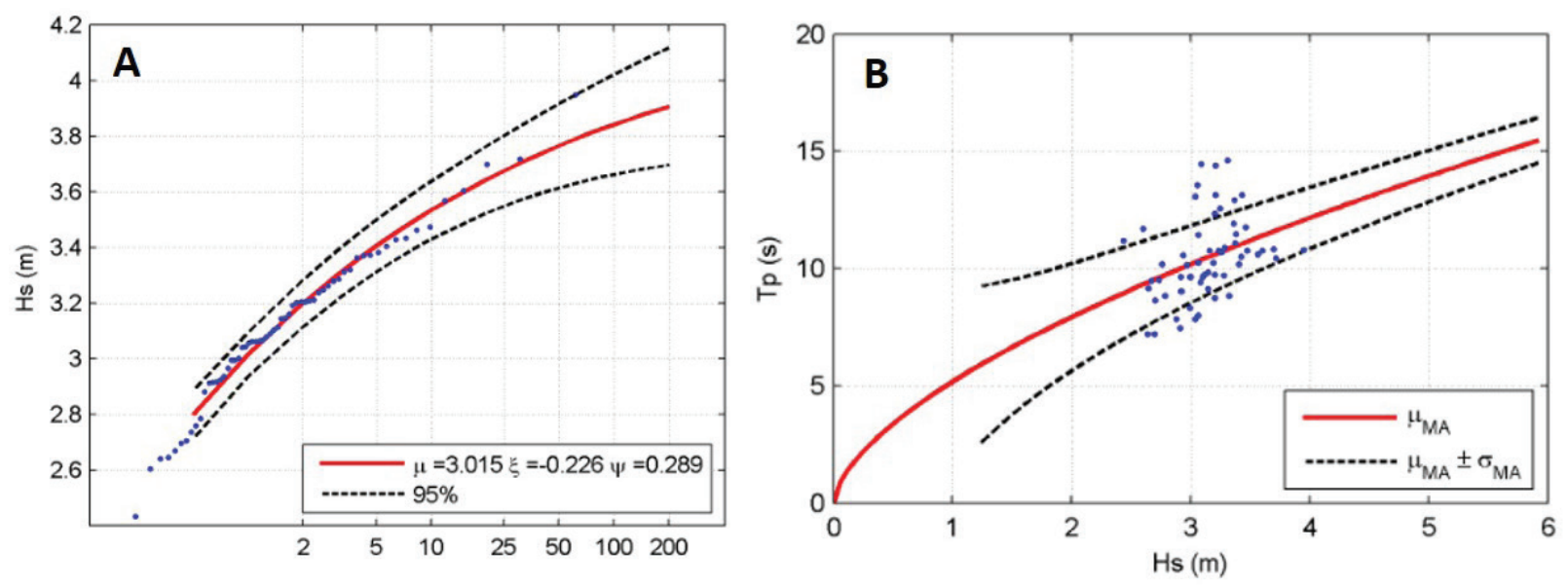

Figure 7. Characteristics of waves with different return periods that affect the study area. A) Extreme regime of significant wave height (Hs) characteristics for different return periods ( $\mathrm{x}$ axis) for the selected DOW point in deep waters adjusted by annual maximum values to a GEV (Generalized Extreme Values) function; and B) Relationship between annual maximum values of extreme significant wave height (Hs) regime and peak period (Tp), where $\mu$ is the location parameter, $\Psi$ is the scale parameter, and $\xi$ is the shape parameter.

Figura 7. Características de ondas com diferentes períodos de retorno que atingem a região de estudo. A) Regime extremos de características de altura significativa de ondas extremas (Hs) para diferentes períodos de retorno (eixo x) para o ponto DoW selecionado em águas profundas ajustado por valores máximos anuais à função GEV (valores extremos generalizados, em ingês); $e$ B) Relação entre valores máximos anuais de altura significativa de ondas extremas (Hs) e sua relação com o período de pico (Tp), onde $\mu$ é o parâmetro de localização, $\Psi$ é a escala do parâmetro e छ́é a forma do parâmetro.

condition waves from ENE (Supplementary Material) and E (Fig. 10 and Supplementary Material) were relatively weak (below 0.4 $\mathrm{m} / \mathrm{s}$ ), presenting small intensifications in the surrounding areas of coral reefs and beachrock outcrops and also over these structures. For more energetic waves (SE - Fig. 11 and Supplementary Material - and SSE - Supplementary Material), higher current magnitude was observed (up to 0.8 $\mathrm{m} / \mathrm{s}$ ), thus indicating higher erosional potential.

There are three smaller reefs connected to the coast between sectors 1 and 2 that subdivided this area current-wise, generating small circulation cells and hampering the transit of currents along the studied coast.

In Sector 1, the frequent presence of coral reefs and beachrock outcrops did not promote a well-defined pattern of currents for this sector. A "snaking" pattern was observed between these structures (Fig. 11), where longshore currents interact with structures and are deflected offshore and then towards the shore again. The currents observed presented low intensity for all four propagated wave directions and an overall weak SWNE longshore current, with intensifications over reefs and beachrocks. Current convergence cells, usually associated with rip currents, can be ob- served between the smaller reefs adjacent to the coast and between tombolos, especially associated with waves from SE (see fig.11 and Supplementary Material). In addition, weak rip currents and small convergence zones are also observable. Coastal erosion in this area may be the result of the increase in longshore transport induced by the beachrock outcrop located at the river mouth.

In Sector 2, the absence of reefs and/or beachrock outcrops adjacent to the beach allowed a more defined pattern in current direction for all wave directions analyzed. For ENE waves, the main current direction was NE-SW, driven mainly by the diffraction produced by the Ponta Grande Reef. These currents converge with SW-NE currents from Sector 1 near the border between these two sectors. However, as the angle of incidence increases (clockwise) this convergence zone migrates northwards, producing rip currents that may transport sediment offshore.

Finally, in Sector 3, the intensification of currents over reefs and the influence they have on current direction becomes more evident. Currents associated with the tombolos converge and produce rip currents that pass through the channels/ openings between and within reefs and move offshore, transporting sediments. 

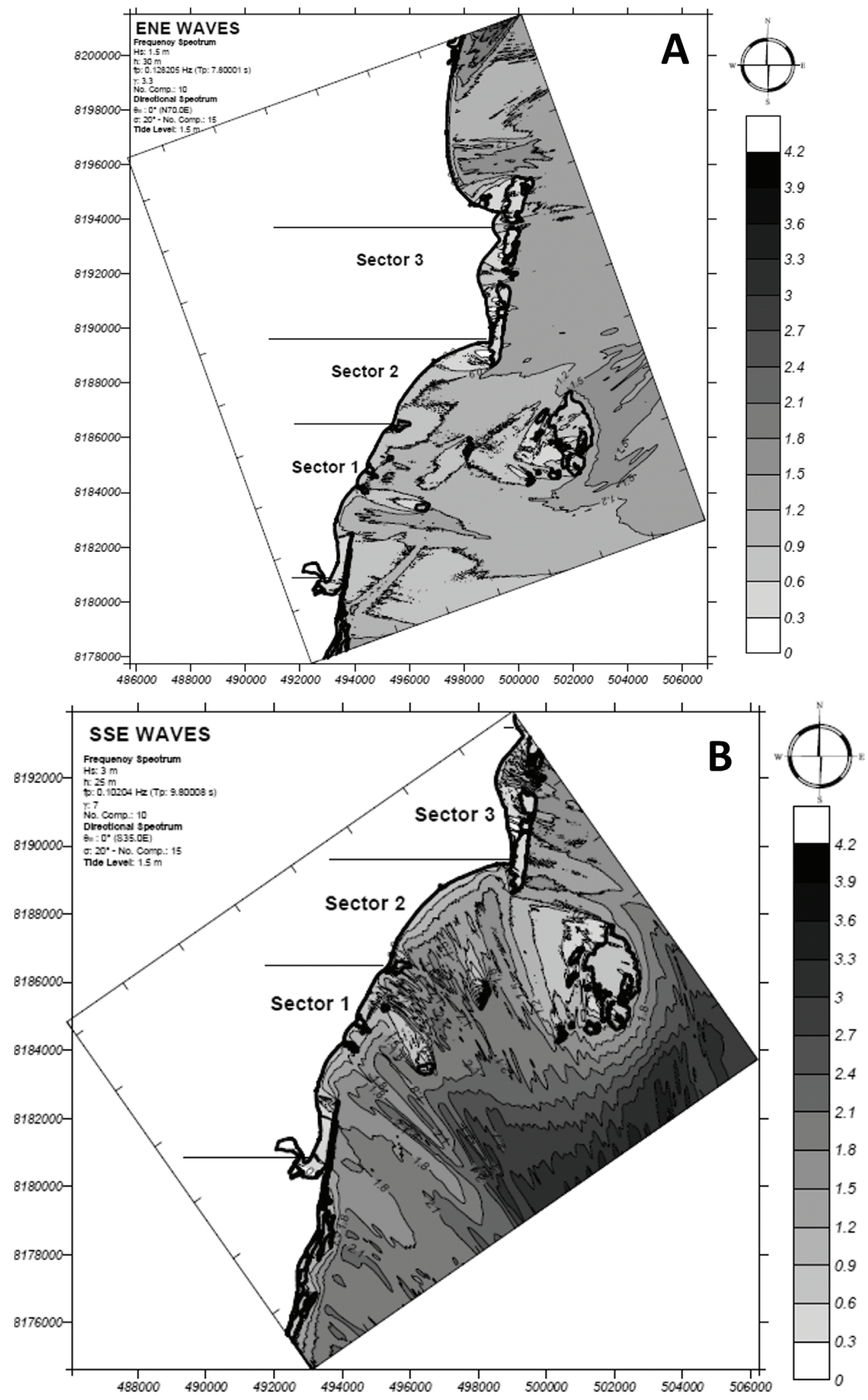

Figure 8: Wave height isoline maps (represented in meters in grey scale, according to the bar presented to the right) for the study area showing results for: A) Example of mean wave conditions (ENE); and B) Example of more energetic (SSE) wave conditions.

Figura 8. Mapa de isolinhas de altura de ondas (representadas em metros em escala de cinza, de acordo com a barra apresentada à direita) para a área de estudo apresentando os resultados para: A) Exemplo de condições médias de ondas (ENE); e B) Exemplo de condições mais energéticas de ondas (SSE). 


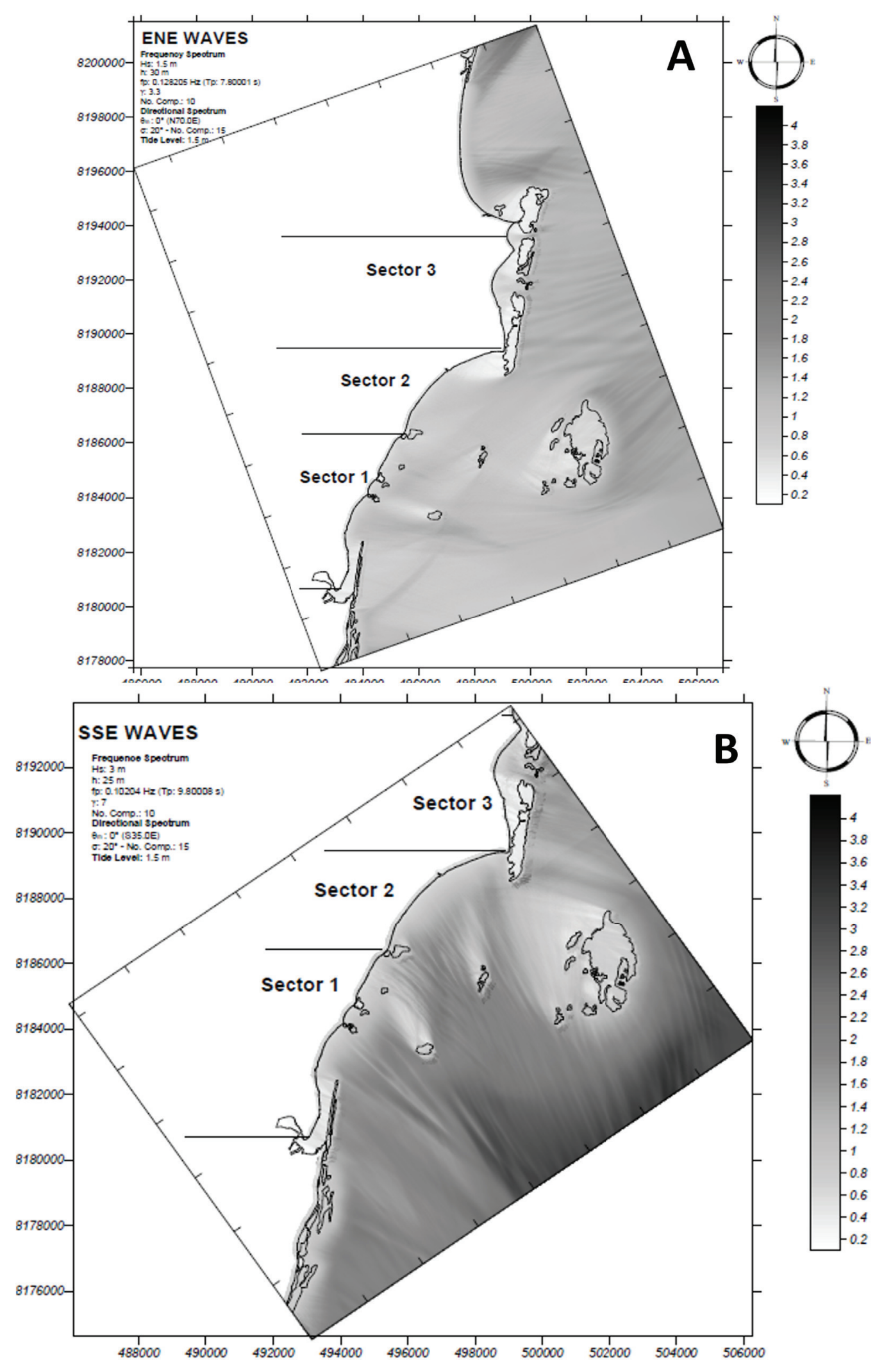

Figure 9. Wave ray incidence (represented in meters in grey scale, according to the bar presented to the right) for the study area for: A) Example of mean wave conditions (ENE); and B) Example of more energetic wave conditions (SSE). Note diffraction patterns caused by reef structures.

Figura 9. Raios de incidência de ondas (representadas em metros em escala de cinza, de acordo com a barra apresentada à direita) para a área de estudo para: A) Exemplo de condições médias de onda (ENE); e B) Exemplo de condições mais energéticas de onda (SSE). Notar os padrões de difração causados pelas estruturas recifais. 


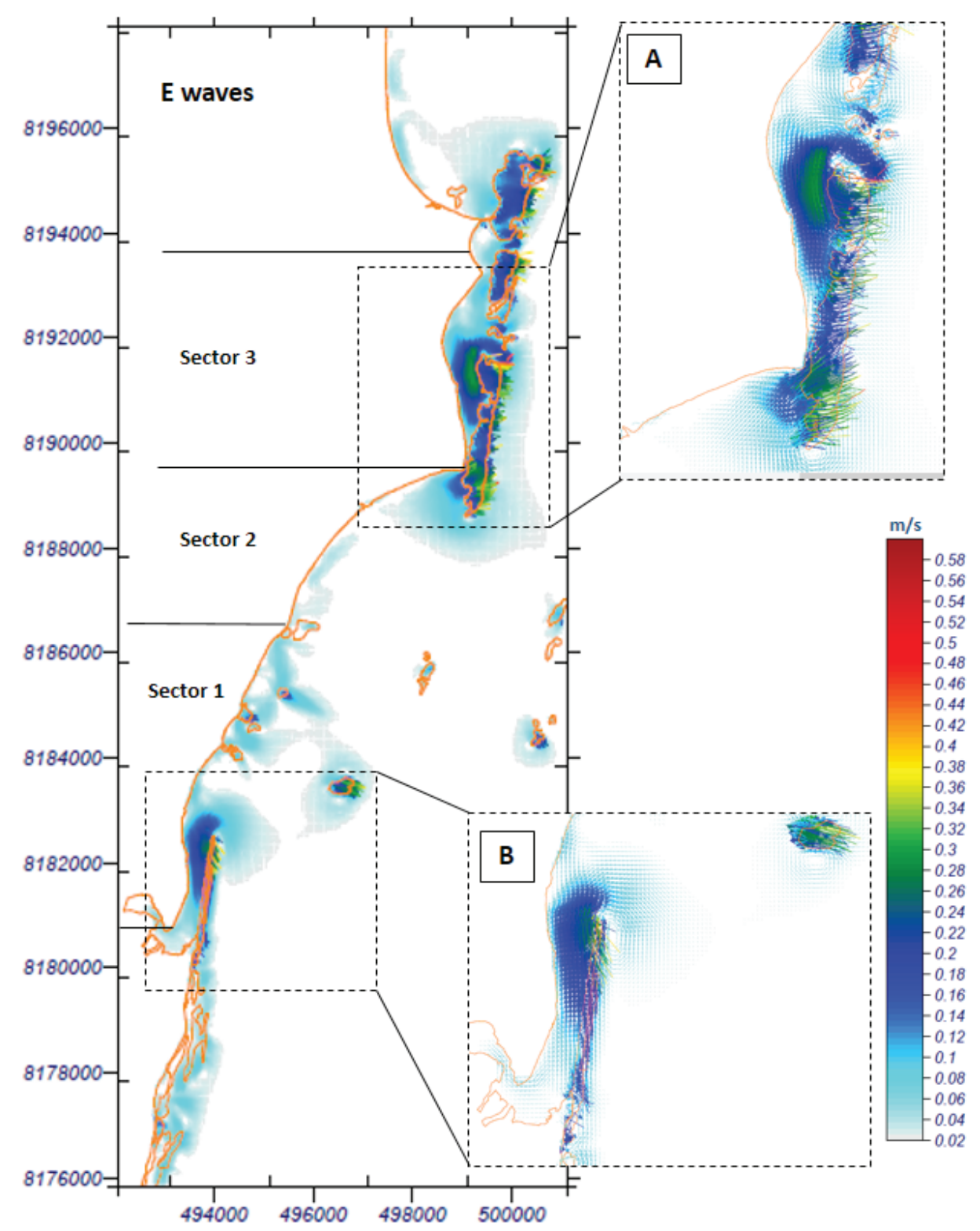

Figure 10. Current intensity and general patterns along the coast of Porto Seguro for E waves. A) Detail showing current intensification over coral reefs (Sector 3); and B) Detail showing current intensification over beachrock outcrops (Sector 1). Note current convergence and rip currents in the openings between coral reefs adjacent to the tombolos in Sector 3. Axes correspond to UTM coordinates.

Figura 10. Intensidade e padrões gerais de correntes ao longo da costa de Porto Seguro para ondas de E. A) Detalhe mostrando a intensificação de correntes sobre os recifes de coral (Setor 3); e B) Detalhe mostrando a intensificação de correntes sobre os afloramentos de beachrock (Setor 1). Notar convergência de correntes e correntes de retorno nas aberturas entre recifes de coral adjacentes aos tômbolos no Setor 3. Os eixos correspondem às coordenadas UTM. 


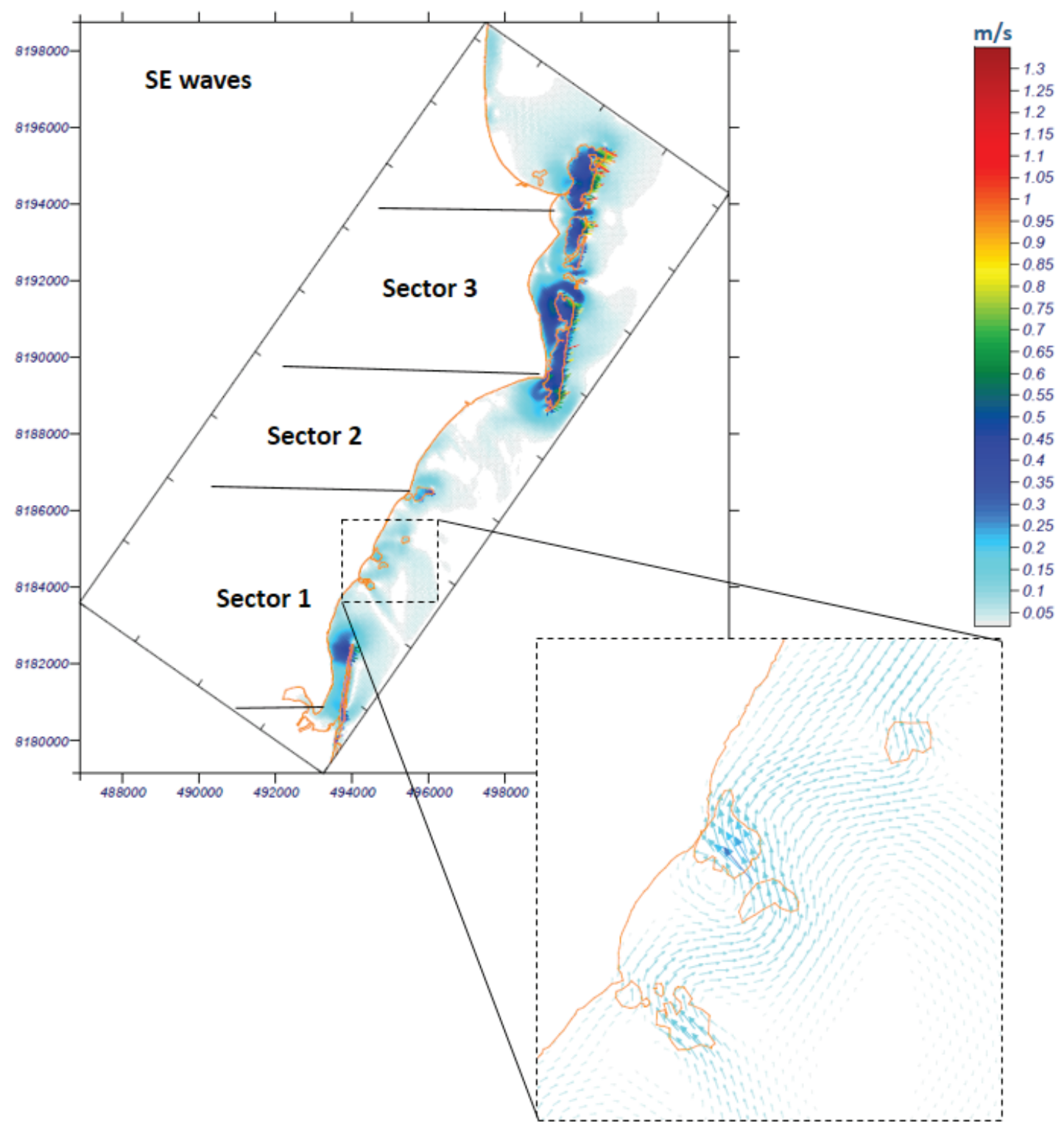

Figure 11. Currents generated by SE waves. Detail shows an example of a "snaking" current pattern over small reef patches adjacent to the coast of Porto Seguro. Axes correspond to UTM coordinates.

Figura 11. Correntes geradas por ondas de SE. Detalhe mostra um exemplo de padrão "serpenteante" de correntes sobre os pequenos bancos recifais adjacentes à costa de Porto Seguro. Os eixos correspondem às coordenadas UTM.

\section{Discussion}

Other studies have successfully used the SMC-Brasil to evaluate erosion problems in coastal areas from Brazil (Almeida et al., 2015, Silva et al., 2016, 2017). Although also presenting limitations intrinsic to this computational tool, their results were satisfactory and well represented the reality of their respective study areas, as the present study.
Over the past decades, coral reefs have been shown to efficiently decrease wave height and wave energy, effectively reducing coastal hazard risks (i.e. Young, 1989; Ferrario et al., 2014). Bittencourt et al. (2010) also indicated that coral reefs and beachrock outcrops in the northern coast of the state of Bahia were responsible for wave energy attenuation. However, as indicated by Elliff \& Silva (2017), the full array of variables involved in shoreline protection by coral reefs has not been 
entirely investigated. Reef morphology (i.e. fringing reefs, barrier reefs, reef patches, atolls, etc.) and rugosity combined to local coastal dynamics yields site-specific results. For example, in the case of the Indian Ocean tsunami of 2004, channels between reefs potentially accelerated the water flow and led to greater coastal flooding behind coral reefs, decreasing their efficiency against coastal flooding (UNEP-WCMC, 2006). In the case of the present study, coral reefs did not seem to protect the shoreline as a whole. The results showed that they potentially induced some of the erosional hotspots currently observed, while protecting other portions of the shoreline. Their morphology, size and distance from the shore combined with different wave directions, yielded different responses regarding coastal erosion. In addition, channels between reef patches adjacent to the tombolos seem to favor the erosion observed in these areas.

During the incidence of cold fronts, more energetic SSE waves reach the beaches that were otherwise protected by ENE and E waves. This fact was also observed by other authors for the north coast of the state of Bahia (Dominguez et al., 1992; Martin et al., 1998; Bittencourt et al., 2005). Wave vectors reach the northern portion of the beach in Sector 2 (Ponta Grande) more directly, since the De Fora reef, which is the largest reef structure near the shoreline, does not cast a shade zone in that direction in these conditions. This reef causes wave diffraction, which associated with the diffraction caused by the Itassepanema reef, allows waves to reach this area more directly. This could be one of the reasons for the erosion observed to cause damages to the BR-367 road in the area.

With increasing efforts towards implementing green infrastructure to promote ecosystem services such as shoreline protection, decision -makers and stakeholders should not overlook the dangers of applying "one size fits all" strategies. Knowledge on local processes is imperative to reach the best outcomes for human well-being and for the environment (Ruckelshaus et al., 2015). Thus, coastal modeling systems such as SMC-Brasil, which compiles wave information for data-deficient areas, present high potential to empower local researchers.

Currents were weak and highly influenced by the presence of structures. Convergence cells migrated northwards as the angle of incidence of waves increased. In the area, reefs and beachrock outcrops were responsible for an intensification of currents. This may be the main cause of the erosion observed along Sector 1. The authors highlight the fact that the "snaking" pattern observed may not entirely represent reality, which may be the result of interpolation of the bathymetry data gap between the limit of the nautical charts $(5 \mathrm{~m})$ and the coast.

The morphology of the coast of Porto Seguro, the frequent presence of reef patches of different sizes, positions and distances from the coast, as well as the uncertainties regarding the definition of the bathymetry, grids and reef shapes and depth, did not allow for an observation of a defined current pattern. This hindered the definition of a preferential direction of currents associated with the various wave directions analyzed.

The insufficient spatial resolution of local winds posed some limitation to the use of SMC -Brasil in this case study. While the most frequent wave directions observed were ESE (50.8\%) and SE (33.1\%), previous regional studies indicated that the most frequent wave directions for the area were E (35\%) and NE (31\%), while waves from SE and SSE accounted for $21 \%$ and $13 \%$ of occurrences, respectively (Hogben \& Lumb, 1967). More recently, Pianca et al. (2010), using NOAA Wave Watch III data, showed that the $\mathrm{N}$ and NE wave signal was present during summer and spring, though at very low frequencies (usually below 10\%). These authors' results showed predominance of $\mathrm{E}$ waves during the summer $(41.3 \%)$, winter (40.5\%), and spring (34.1\%). During autumn, S waves predominated $(47.3 \%)$. The S and SE components were present in relevant frequencies during all seasons. An underrepresentation of waves from the NE quadrant was also observed by Silva et al. (2016, 2017).

In order to overcome the system's deficiency, a northeastern wave quadrant case (ENE) was created based on the literature in order to evaluate the local incidence of waves from this direction. Although the wind field may underestimate the incidence of $\mathrm{NE}$ waves, the time-averaged results showed fine agreement between modeled and ob- 
servational data from other studies and the results found in the present study.

Another important aspect regarding potential for coastal erosion and coastal management strategies were the return periods observed in the present study. Waves measuring $3 \mathrm{~m}$ in height and with peak periods of approximately $10 \mathrm{~s}$ presented a return period of over one year, indicating that their incidence is relevant, frequent, and must be taken into account when considering coastal management and risk reduction. In addition, more energetic events presented return periods of two and five years, thus increasing ongoing erosional processes. This should be taken into account by decision makers when planning interventions in the coastal zone of Porto Seguro, such as the construction of shoreline protection structures.

Coastal erosion fits the definition of hazard proposed by the United Nations International Strategy for Risk Reductions (UNISDR, 2009), considering that this process represents a condition that may promote injuries, loss of life, damage to property, loss of livelihoods, social and economic disruption, and environmental damage. As such, vulnerable areas should seek strategies to increase their resilience, allowing local communities to recover fully from adverse events.

As shown in the present study, the municipality of Porto Seguro already faces the impacts of coastal erosion, especially in the area of Ponta Grande where part of the BR-367 road has been damaged. Management strategies should be applied in the area and should take into account the particularities of the area in order to be effective in tackling the problem. The construction of underwater breakwaters was suggested by other authors as a possible solution for erosional problems in northeastern Brazil (Mallman \& Pereira, 2014). This was specifically suggested due to the fact that these structures simulate coral reefs. However, due to the geomorphology complexity of Porto Seguro, such engineering interventions should be carefully considered before being implemented in order to avoid future problems. The managemennt strategies "accommodate", "expand into the coastal zone" and "hold the line" proposed by the Wellington City Council Sea Level Rise Option Analysis report (WCC, 2013) should be a possible solution for
Porto Seguro to cope with an imminent sea-level rise. The first couple of strategies could be used in the case of the recreational complexes (bars and restaurants) found on the shoreline that not only suffer from the consequences of coastal erosion, but also seem to induce them. These structures could be relocated or rebuilt as suspended structures (stilts) to reduce the effects of sea-level rise. In turn, for the BR-367 road, the last couple of strategies could be implemented. Therefore, the road could be either elevated of moved into the coastal zone. In addition to these strategies, the removal of ripraps, beach nourishment and reforestation of lost areas of dune vegetation should be implemented.

\section{Conclusions}

Although different (in terms of magnitude and frequency) from the regional results found in the literature, the local wave results of the present study agreed with general patterns found in modeled and observational studies, thus indicating that SMC-Brasil can be successfully applied in Brazilian beaches, especially for management purposes.

The various coral reef structures present adjacent to the coast are responsible for uneven wave energy distribution along the coast by creating low wave energy zones and focuses of higher wave magnitude as a result of wave diffraction.

Waves from SE and SSE seem to be responsible for the most concerning erosion hotspot of the area (sector 2), which is intensified under stormy conditions. Thus, the present study represents an important baseline for local decision makers to effectively respond to the severe erosional problem that constantly damages the most important access road (BR-367) between the center of the municipality and districts located along the tombolos, causing great losses to the local population. Moreover, the present study provides important information about the local dynamics at the most detailed level yet, which may aid future coastal engineering projects designed to solve or mitigate problems caused by coastal erosion.

Acknowledgments. G. Fernandino thanks the $\mathrm{Na}$ tional Council for Scientific and Technological Deve- 
lopment (CNPq) for his $\mathrm{PhD}$ scholarship (Process No. 140817/2014-0) and the Environmental Hydraulics Institute, Universidad de Cantabria, Spain, for providing data and training and for supporting this study. He also thanks Carla Elliff for her valuable insights and discussions from the point of view of ecosystem services that greatly contributed to the present study. M. González and V. Cánovas acknowledge the support of the Sociedad para el Desarrollo Regional de Cantabria (SODERCAN) under Grant ID16-IN-045.

\section{References}

Adams, P.N., Inman, D.L. \& Lovering, J.L. 2011. Effects of climate change and wave direction on longshore sediment transport patterns in Southern California. Climate Change, 109(Suppl. I): S2011-S228.

Almeida, L.R., Amaro, V.E., Marcelino, A.M.T. \& Scudelare, A.C. 2015. Avaliação do clima de ondas da praia de Ponta Negra (RN, Brasil) através do uso do SMC-Brasil e sua contribuição à gestão costeira. Journal of Integrated Coastal Zone Management, 15(2): 135-151.

Bittencourt, A.C.S.P., Dominguez, J.M.L., Martin, L. \& Silva, I.R. 2000. Patterns of sediment dispersion coastwise the state of Bahia-Brazil. Anais da Academia Brasileira de Ciências, 72(2): 271287.

Bittencourt, A.C.S.P., Dominguez, J.M.L., Martin, L. \& Silva, I.R. 2005. Longshore transport on the northeastern Brazilian coast and implication to the location of large-scale accumulative and erosive zones: an overview. Marine Geology, 219(4): 219-234.

Bittencourt, A.C.S.P., Livramento, F.C., Dominguez, J.M.L. \& Silva, I.R. 2010. Tendência de longo prazo à erosão costeira num cenário perspectivo de ocupação humana: litoral norte do estado da Bahia. Revista Brasileira de Geociências, 40(1): 125-137.

Camus, P., Mendez, F.J., Medina, R., Tomas, A. \& Izaguirre, C. 2013. High resolution downscaled ocean waves (DOW) reanalysis in coastal areas. Coastal Engineering, 72: 56-68.

CEPAL. Comisión Económica para América Latina y el Caribe. 2011. Efectos del cambio climático en la costa de América Latina y el Caribe: dinámicas, tendencias y variabilidad climática. NU, CEPAL, 265p.

Dominguez, J.M.L. 2000. Projeto Costa do Descobrimento: avaliação da potencialidade mineral e subsídios ambientais para o desenvolvimento sustentável dos municípios de Belmonte, Santa Cruz de Cabrália, Porto Seguro e Prado. Salvador, CBPM/CPRM - CBPM/UFBaCPGG/LEC, 163p.

Dominguez J.M.L, Bittencourt A.C.S.P. \& Martin L. 1992. Controls on Quaternary coastal evolution of the east-northeastern coast of Brazil: roles of sea-level history, trade winds and climate. Sedimentary Geology, 80:213-232.

Dominguez, J.M.L., Martin, L. \& Bittencourt, A.C.S.P. 2002. A Costa do Descobrimento, BA: a geologia vista das caravelas. In: Schobbenhaus, C., Campos, D.A., Queiroz, E.T., Winge, M. \& Berbert-Born, M.L.C. (Eds.) Sítios Geológicos e Paleontológicos do Brasil. Brasília, DNPM/ CPRM/SIGEP, p. 233-241.

Elliff, C.I. \& Silva, I.R. 2017. Coral reefs as the first line of defense: Shoreline protection in face of climate change. Marine Environmental Research, 127:148-154.

Ferrario, F., Beck, M.W., Storlazzi, C.D., Micheli, F., Shepard, C.C. \& Airoldi, L. 2014. The effectiveness of coral reefs for coastal hazard risk reduction and adaptation. Nature Communications, 5: 1-9. González, M.,Medina, R., Gonzalez-Ondina,J.,Osorio, A., Méndez, F.J. \& García, E. 2007. An integrated coastal modeling system for analyzing beach processes and beach restoration projects, SMC. Computers \& Geosciences, 33(7): 916-931.

González, M., Nicolodi, J.L., Gutiérrez, O.Q., Losada, V.C. \& Hermosa, A.E. 2016. Brazilian coastal processes: wind, wave climate and sea level. In: Short, A.D. \& Klein, A.H.F. (Eds.), Brazilian Beach Systems. Switzerland, Springer International Publishing, 608p.

Griggs, G.B. \& Trenhaile, A.S. 1997. Coastal cliffs and platforms. In: Carter, R.W.G. \& Woodroffe, C.D. (Orgs.) Coastal Evolution-Late Quaternary shoreline Morphodynamics. Cambridge, Cambridge University Press, p. 425-450.

Hogben, N. \& Lumb, F.E. 1967. Ocean Wave Statistics. London, HMSO, 263p. 
Leão, Z.M.A.N. \& Kikuchi, R.K.P. 1999. The Bahian coral reefs - from 7000 years BP to 2000 years AD. Ciência e Cultura, 51: 262-273.

Liu, P.L.F. \& Losada, I.J. 2002. Wave propagation modeling in coastal engineering. Journal of Hydraulic Research, 40(3): 229-240.

Mallmann, D.L.N. \& Pereira, P.S. 2014. Coastal erosion at Maria Farinha Beach, Pernambuco, Brazil: Possible causes and alternatives for shoreline protection. Journal of Coastal Research, 71(SI):24-29.

Martin, L., Dominguez, J.M.L. \& Bittencourt, A.C.S.P. 1998. Climatic control of coastal erosion during a sea-level fall episode. Anais da Academia Brasileira de Ciências, 70: 249-266.

Masselink, G. \& Gehrels, R. 2014. Introduction to coastal environments and global change. In: Masselink, G. \& Gehrels, R. (Eds.) Coastal environments \& global change. Chichester, West Sussex, John Wiley \& Sons, Ltd., p. 1-25.

Mori, N., Yasuda, T., Mase, H., Tom, T. \& Oku, Y. 2010. Projection of Extreme Wave Climate Change under Global Warming. Hydrological Research Letters, 4: 15-19.

Pianca, C., Mazzini, P.L.F. \& Siegle, E. 2010. Brazilian offshore wave climate bases on NWW3 reanalysis. Brazilian Journal of Oceanography, 58(1): 53-70.

Reguero, B.G., Menéndez, M., Méndez, F.J., Mínguez, R. \& Losada, I.J. 2012. A Global Ocean Wave (GOW) calibrated reanalysis from 1948 onwards. Coastal Engineering, 65: 38-55.

Ruckelshaus, M., Mckenzie, E., Tallis, H., Guerry. A., Daily, G., Kareiva, P., Polasky, S., Ricketts, T., Bhagabati, N., Wood, S.A. \& Bernhardt, J. 2015. Notes from the field: lessons learned from using ecosystem service approaches to inform realworld decisions. Ecological Economics, 115:1121.

Silva, I.R. 2004. Costa do Descobrimento: uma contribuição para gestão ambiental. Salvador, 232 p. Tese de Doutorado, Programa de Pós-graduação em Geologia, Instituto de Geociências, Universidade Federal da Bahia.
Silva, I.R., Bittencourt, A.C.S.P., Dominguez, J.M.L. \& Silva, S.B.M. 2003. Uma contribuição à gestão ambiental da Costa do Descobrimento (litoral sul do estado da Bahia): Avaliação da qualidade recreacional das praias. Geografia, 28(3): 397413.

Silva, I.R., Guimarães, J.K., Bittencourt, A.C.S.P., Rodrigues, T.K. \& Fernandino, G. 2016. Modelagens de clima de ondas e transporte sedimentar utilizando o SMC-Brasil: aplicações para a Praia do Forte, litoral norte do estado da Bahia. Revista Brasileira de Geomorfologia, 17(4):743-761.

Silva, I.R., Guimarães, J.K., Bittencourt, A.C.S.P., Rodrigues, T.K. \& Fernandino, G. 2017. Avaliação da dinâmica litorânea da região de Baixio/Barra do Itariri, litoral norte do Estado da Bahia, utilizando o Sistema de Modelagem Costeira (SMC-Brasil). Pesquisas em Geociências, 44(2):221-234.

UNEP-WCMC. United Nations Environment Programme World Conservation Monitoring Centre. 2006. In the front line: shoreline protection and other ecosystem services from mangroves and coral reefs. Cambridge, UNEPWCMC, 44p.

UNISDR. United Nations International Strategy for Risk Reductions. 2009. Terminology on Disaster Risk Reduction. Geneva, United Nations, 35p.

WCC. Wellington City Council. 2013. Sea Level Rise Options Analysis. Wellington: Tonkin \& Taylor Ltd.

Young, I.R. 1989. Wave transformation over coral reefs. Journal of Geophysical Research, 94(C7):9779-9789. 